\title{
Explaining governance failure: accountability spaces in-between and bias.
}

Accepted for publication by the International Journal of Critical Accounting (August 2012)

Oliver Marnet

\begin{abstract}
The paper is based on a two-year participant observer study of the governance failures in a UK housing association that experienced significant adverse performance resulting in its near collapse. Concerned with the accountability of boards of directors, the study extends research by Roberts $(1991,1996,2001)$ who distinguishes between formal and informal forms of accountability, and Collier (2005) who identifies accountability spaces in-between where governance may be lost. The present research builds on this discussion by introducing socio-psychological factors underlying a reluctance of boards to adequately explore governance issues hidden in these spaces. As informal reporting systems are increasingly important drivers of the control role of boards (Parker, 2008), the paper emphasizes the need for boards to adopt procedures aimed at mitigating the effects of bias on the quality of board decision-making.
\end{abstract}

Keywords: Quasi-public sector; governance; accountability; boardroom decisionmaking; bias mitigation; new public management;. 


\section{Introduction}

The paper explores limitations of formal, accounting-based systems of accountability and inadequacies of informal, sense-making narrative systems (Roberts, 1991, 1996, 2001; Collier, 2005). The sense-making narrative terminology builds on the contrast made by Roberts (1991) between a formal, hierarchical system of accountability based on calculative accounting, and an informal, socialising form, which in boardroom discussions increasingly replaces the focus on the technical and rulebased (Parker, 2008). Hidden between the two systems, Collier (2005) identifies accountability spaces in-between where neither the formal nor the informal ensures that issues important to the organization are sufficiently explored and where governance can be neglected and lost. The present research inquires into sociopsychological causes for the reluctance of boards to investigate these spaces. The paper suggests that cognitive bias in judgment frequently inhibits an adequate articulation and exploration of issues critical to the governance of organizations, thereby undermining the value of the narrative form of accountability (Langevoort, 2001a,b; Prentice, 2003; Bazerman and Malhotra, 2006; Forbes and Watson, 2010; FRC, 2011; APB, 2012).

With the rise of New Public Management (NPM) and the subsequent increase in the use of performance measurement in the quasi-public sector (Collier, 2005; Bogt and Scapens, 2012), a discussion on bias in the boardroom provides useful insights on potential problems and dysfunctional consequences of the adoption of this model in the public sector (see, e.g., Hood, 2007; McLean et al., 2007; Broadbent and Guthrie, 2008; Lapsley, 2008). New Public Management, although changing over time and from country to country, stresses the use of explicit quantitative performance 
measures and external audits, output controls, and private sector management methods to advance public sector performance and accountability (Hood, 1995, 2007; Pollitt, 2006; de Bruijn, 2007; Woods, 2010; Bogt and Scapens, 2012). A reliance by boards on quantitative performance measures as expressions of formal accountability may, however, not be warranted when bias in the boardroom leads to the failure of the narrative to provide a counterbalance to managerial discretion over these measures.

The case study serves to illustrate the impact of bias on the quality of a board's decision-making (FRC, 2011; APB; 2012). The two-year participant observer study, with the researcher as a full member of the board, analyzes board interfaces with executive management of a UK housing association (subsequently referred to as 'the Association'), with a focus on the role of accountability in the processes of governance before, during, and after a crisis of confidence and subsequent restructuring. The Association suffered a rapid transition from a successful organization to one which experienced near fatal failures in financial and operational management. Central to this transformation was the board's loss of control over the organization when it neglected to explore issues that had been hiding in the spaces identified by Collier (2005).

The paper is structured as follows. The second section outlines the context of the study and explores the theoretical concepts introduced above. The third section describes elements of the field study. Building on the notions of calculative and narrative accounting (Roberts, 1991; Collier, 2005), the fourth section links the case to the theoretical framework, and discusses cognitive bias as a factor which affects 
board effectiveness by inhibiting an adequate exploration of accountability spaces inbetween. The final section presents the conclusions.

\section{Context of the study}

Corporate governance has been defined as "the system by which organizations are directed and controlled" (Cadbury, 1992), and as being "concerned with structures and processes for decision-making, accountability, control and behavior at the top of organizations" (IFAC, 2001, p.1). Although primarily focused on the private sector, the governance paradigm developed in the UK over the past two decades (Gwilliam and Marnet, 2010) applies to housing associations with their general adoption of the Cadbury Code of Best Practice (Cadbury, 1992), and broad adherence to recommendations of subsequent reviews and guidelines of the UK governance framework with regard to external audit and the responsibilities of the board.

Housing associations construct and manage housing for groups on low incomes or with support needs, and have an increasing role in the provision of social housing in the UK after the significant downsizing and outsourcing of public-sector involvement since the late 1980s. Over the past two decades, these organizations have moved from mainly small scale complementary roles to the large scale delivery of public services, and are the predominant vehicle for the delivery of affordable housing (Wilcox, 2004; Mullins, 2010). By 2009, housing associations in England owned some 2.4 million rental units (either purpose built, or acquired through stock transfer from local councils), 95 per cent of which used for social housing (Tang, 2010). Substantial initial funding, and much of the continuing funding flow, is provided through public sector capital grants and housing benefits which form some 65 per 
cent of the sector's rent income (Collier, 2005; Mullins, 2010; Tang, 2010). Additional funds are provided through private financial market loans, with lenders typically requiring a 30 -year business plan outlining projected income and expenditure streams to ensure that cash flows cover the principal and interest payments (TSA, 2012; Community Housing, 2011). The book value of the sector's housing assets in England 2010/11 reached £109 billion (Wales and Scotland operate and regulate their own schemes), supported by $£ 45$ billion of private finance and some £40 billion grant (TSA, 2012).

Social housing in the UK is subject to a high level of regulation and periodic audit/inspection, and mandatory financial reporting requirements are met through a system of formal accounting and external audit, as one component of accountability (Collier, 2005; TSA, 2012; Community Housing, 2011). From 2002 onward, rent increases for housing associations in England have been capped by a guideline limit of the Retail Price Index (RPI) $+0.5 \%$ (DETR, 2001; TSA, 2012), with comparable constraints to rent increases in Scotland and Wales (Community Housing, 2011). Regardless of the not-for-profit orientation of such organizations, their boards must deal with issues of financial planning and control, regulatory and managerial oversight, governance, pension liabilities, and financial responsibilities for the assets under their control. Their non-executive directors hold responsibilities, and face conflicts, similar to those of directors of listed companies, related to the setting of organizational objectives, monitoring of performance, scrutiny of financial reports, and the supervision of executive management (Brudney, 1982; Fama and Jensen, 1983; Daily et al., 1996; Ezzamel and Watson, 1997; Hermalin and Weisbach, 1998; Higgs, 2003; Brennan, 2006). These responsibilities are set in an environment of 
multiple stakeholders with frequently opposing agendas and demands, which sharpens and complicates the contrast between a traditional sector focus on service provision and the need to manage short and long-term financial commitments (Collier, 2005; Mullins, 2010).

A focus of New Public Management on quantitative measurability gives "primacy to accounting practices and processes" (Kurunmäki et al., 2011, p. 1), with key importance allocated to professional managers in the implementation of policies set for the public sector (Hood, 1995). One consequence of this focus on professional managers is a concentration of discretional power over accounting practices and processes at the executive level. The potential use of these discretional powers to influence what is expressed in formal accounts, in combination with inherent limitations to "the capability of accounting calculations to identify the absolute truth" (McSweeney, 1996, p. 217), suggests that formal accounts provide only partial and limited expressions of a board's accountability (see Collier, 2005, for a discussion of these limits). The narrative, then, as a driver of the exercise of control, necessarily shares and defines the discharge of a board's responsibilities to its stakeholders (Parker, 2008). This resonates with interpretations that calculative forms of accountability cannot replace responsibilities of judgment and opinion which remain dependent on, and should find expressions in, narrative systems of accountability (Hoskin, 1996; Kamuf, 2007). By adopting elements of a paradigmatic approach to good corporate governance in terms of an overall focus on appropriate internal control and risk management (see Gwilliam and Marnet, 2010), boards of quasipublic sector organizations (Collier, 2005) face traps and pitfalls in implementation not dissimilar to those experienced by listed companies (FRC, 2011). The following 
analysis of the events at the Association demonstrates that the informal form of accountability is exposed to a number of bias inducing factors which can affect the quality of boardroom decision-making, with the potential to diminish the contribution of the narrative as a tool of board control (Forbes and Watson, 2010; Marnet, 2011; FRC, 2011; APB, 2012).

\section{Field study}

The participant-observer methodology enables first-hand insights into a number of issues which impact on a board's willingness to explore accountability spaces. However, the need to preserve confidentiality constitutes a challenge for this approach with regard to the use of supportive evidence for observations and assertions where detailed substantiation would allow for the identification of the organization under investigation (Parker, 2008). Despite this constraint, there are few substitutes for observations of actual board meetings by a researcher in developing an understanding of factors influencing board effectiveness (Heracleous, 1999), and key weaknesses in the governance and control mechanisms of the Association can be identified to inform the discussion. Basic facts and a chronology of key events are summarised at this point to support the subsequent analysis.

\subsection{Key facts}

\section{Governance framework (prior to the re-organization):}

- Nominal adherence to Cadbury recommendations (Cadbury, 1992), supervised by sector regulator and subject to periodic inspections, responsibilities to diverse group of stakeholders.

- Long acting CEO, Chair and external auditor.

- Board composed of up to 15 non-executive directors: 8 (typically longacting) elected (and re-elected) by 'shareholders' at the Annual General 
Meeting (upon approval by the board, interested parties can become members through payment of £1), 4 tenant members elected by tenants, and up to 3 co-opted members (not always filled).

- CEO and CFO traditionally attending board meetings.

Indicative chronology of events:

Until 2003

Steady growth in revenue base (mainly housing units under management) and close matching of revenues with expenditures. Positive cash flows and creation of substantial cash reserves.

From 2003 Increasing divergence between (near static) revenues and (rapidly rising) expenditures (mainly due to staff expansion and above sector average salaries). Board largely unaware, while emerging concerns by individual directors remain largely unarticulated. The Association increasingly operates at a deficit.

Early 2007 Cash reserves exhausted.

Late 2007

Highly critical verdict by independent inspection report on the quality of service provision, which put in question the ability of the Association to remain independent, acts as catalyst for board action.

Late 2007 to Significant restructuring and re-orientation of the early 2009 Association (new CEO and CFO, emergency board meetings, away days, task and finish groups, meetings with stakeholders and regulator, replacement of external auditor, imposition of outside directors, etc.).

Mid-2009 Association regains financial footing, and the trust of the regulators and financial sector stakeholders. Resumes normal business operations. 


\section{$\underline{\text { Key Governance weaknesses: }}$}

- Executive management team in place for a long time (issues for the board of familiarity, trust, complacency, confidence in prior performance vs. CEO).

- Board in place for a long time (familiarity, socialisation, prior decisions).

- External auditors in place for a long time (familiarity, loss of critical attitude, loss of independence, prior decisions).

- Dominant chair and CEO who set the board agenda and controlled board meetings (lack of critical performance review, unwarranted trust, socialization, peer pressures).

- Large board size (reliance on other members to raise issues, free rider issues, poor communication, unwarranted trust in senior members).

- Limited direct contact between the board and external auditors (no direct communication, no voicing of critical issues by the auditor, no critical questions to the auditor).

- Failure of executive management to recognise failures in service provision of the organization and to balance increased operating costs with near static revenues (a management failure, not queried by the board).

- Critical information withheld from the board (a classic feature of almost all governance failures).

- Financial presentations to the board lacking detail; data incomplete, late, inadequate (not forcefully questioned by board).

- Weak internal audit function (very poor record keeping, lack of critical input to board meetings, inadequate, unreliable, untimely data not queried by the board).

- Board members' limited financial and accounting experience and limited training of board members (lack of expertise, failure to fully understand financial data, failure to realise limitations of financial data in the discharge of board responsibilities, little comprehension of roles, duties, and powers of board). 
- Apprehensions of board members not voiced during board meetings (failure to explore spaces, loyalty bias, and socialization).

- Failure of the board to accept the need for change prior to the devastating inspection report, and reluctance to support changes as a matter of urgency (preference of status quo, excessive loyalty to CEO, dissonance reduction).

\subsection{The Association}

The Association was established by the merger of two housing associations more than 15 years prior to the described events, and is governed by a board of management of 15 non-executive members, with minor variations in membership numbers and composition over time (mergers between housing associations reflect a trend, see Tang, 2010). The CEO and members of executive management of the Association traditionally attended those parts of board meetings not explicitly related to issues related to management performance. Regulation of the Association takes place through best practice guidelines, reinforced by regular financial reporting requirements, performance measurement comparisons, periodic inspections by and on behalf of the sector's regulator, and through dialogue with key stakeholders (Mullins, 2010; Tang, 2010). Financial and operational control is exercised through the business plan and the budget (Collier, 2005; Tang, 2010; TSA, 2012), reported by the CEO through board presentations, mission statement, core values, planned outcomes, key performance indicators, and sector comparisons (outlined in the Association's internal and published documents).

Strategic orientation at the Association was found to be the primary driver of the board's exercise of control, with less emphasis on a critical review of the reporting system, monitoring of management, and risk management, which mirrors earlier 
results by O'Neal and Thomas (1995), Leatherwood and O'Neal (1996), Miller (2002), and Peck (2005). A mixed picture on the control orientation of the board is revealed as it struggled with and towards accountability. Leading up to the crisis of confidence at the Association, observations of board meetings support earlier reviews of boards of not-for-profit organizations as mainly passive recipients of information who rarely rise to challenge managerial presentations (Peck, 1995). Board meetings were strongly dominated by the CEO and the Chairman. The CEO and the Chairman invariably set the board agenda and took a strong lead in directing the discussion, which typically yielded majority decisions in agreement with management. The locus of control was initially held by the CEO, with the Chairman a very close second (after the crisis, this shifted permanently and decisively to the Chair).

Observations of the board atmosphere prior to the crisis, and informal discussions with directors, indicate a high level of familiarity, bonding, trust, and a sense of common objectives among board members. The board's trust in the adequacy of its own control performance had largely been based on faith in the legitimacy of the formal reporting system and presentations by a trusted CEO (as one director expressed: "We adhere to the reporting requirements set by the regulator and follow sector best practice". - "Our CEO has been with us since the beginning and has weathered many storms. He knows the sector, and we trust him"). Nevertheless, informal conversations surrounding board meetings in early 2007 indicated emerging concerns about the Association's formal accounts, performance and direction (postcrisis, accounts were found by the Chair to be "inadequate, untimely, and incomplete"). These concerns had, however, not been voiced during board meetings 
until the presentation to the board in late 2007 of the findings of an external audit inspection on the quality of service provision revealed serious shortcomings in the Association's operations (the head of the audit team referred to the Association as '... a failed housing association.... - While the report of this routine audit inspection is in the public domain, referencing the document is omitted as this would conflict with the need to preserve confidentiality). By implication, although not by remit, the key findings of the audit raised immediate questions about the financial viability of the Association, prompting action by the board to ensure its survival as an independent organization.

Little self-reflection on accountability of and by the board had taken place prior to these third party expressions of concern (one board member noted that: "There were some concerns in the past few years about missing or late figures, but when put to the CEO during informal talks before or after board meetings, these were usually met with promises of follow-up. The matter was generally not pursued and not raised during board meetings, as it was not seen as a serious issue.... we all felt that the Association was doing a sterling job in providing affordable housing to the community and that we were operating on a sound financial basis."). Confidential Association data compiled in late 2007 revealed, however, that the Association's financial situation had started to deteriorate from 2003 onward as a result of substantially increased operating costs against a near static revenue base. The escalation in costs was mainly due to significant increases in staff numbers and above sector remuneration, contrasted by relatively stagnant revenues as a result of a near constant level of assets under management (source: researcher's review of historic internal Association data and comparison to sector data). The divergence 
between costs and revenues widened in the subsequent four years, and by 2007 the Association had been transformed from an organization with a positive cash flow and substantial cash reserves (prior to 2003) to one which operated at an annual loss with no substantial reserves (additional source: confidential Association data compiled in 2007/08).

Ultimately, the audit verdict served to sharply focus the minds of board members, motivated articulation of critical issues and acted as a catalyst for a thorough and lengthy, but at times acrimonious, process of introspection and restructuring. From end-2007 and through the whole of 2008 the board put in motion a large number of initiatives to change the direction of the Association and enhance the quality of its governance. The incumbent CEO and the Director of Finance left the Association and an interim CEO (supported by an interim Director of Finance) was tasked to reorganize the Association, implement a sound system of internal control and accounting, provide reliable, timely and adequate information to the board, put the Association on a stable financial base, address the service issues raised by the independent audit, and mend the strained relationships with the regulator, principal lenders and other stakeholders.

The initial impetus for organizational change came from a small, but determined, minority of incumbent board members, the efforts of the interim CEO (subsequently made permanent), and a dedicated group of core staff. Aspects of the restructuring focussed on frequent (regular and emergency) board meetings, away-days, meetings with various stakeholders (including the organization's regulator and private sector financial institutions) and brainstorming sessions between key staff, 
the new interim CEO, a newly created Task \& Finish group, board members, and external advisors. The number of regular board meetings increased from quarterly to monthly meetings during the 18 months of restructuring and a broad spectrum of meetings, which the vast majority of board members attended, took place on a near weekly basis, with some weeks containing several such meetings.

A key ingredient to the, ultimately successful, restructuring process was the contribution of a small group of new board members with a housing association background at executive level, who joined the board at the behest of the regulator with a strictly time-limited (one year) remit to enhance the governance capabilities at the Association. During their time on the board, and against initial apprehensions by established members who feared an erosion of their role, the guidance of these directors was instrumental to efforts of the board to regain control over the organization. The quality of decision-making of the board improved notably over the following months, with board level deliberations becoming significantly more informed by concerns about, and an understanding of, accountability and the contribution and limitations of formal accounts. By June 2009, the regulator indicated (through confidential communications relayed to the board in June 2009) that the Association had re-gained sufficient financial footing, implemented an acceptable internal control system, and made significant progress in addressing key service quality issues arising from the 2007 audit. This allowed the Association to remain independent and enabled a re-focus on the provision of social housing as an organizational core objective. 


\section{Discussion}

Neither the formal nor the informal form of accountability, on its own or in combination with the other, may yield meaningful board control over an organization (Collier, 2005). In the course of typical boardroom discourse, important concerns may fail to be expressed and inadequacies of the formal form of accountability may remain unchallenged until critical issues of organizational performance enter the public domain (Parker, 2008; APB, 2012). While corporate scandals are frequently associated with issues of corruption, fraud, incompetence, and ethical failure of key governance agents, including that of members of the board (Clarke et al., 2003; Marnet, 2007; Gwilliam and Marnet, 2010), the bigger issue may be one of flawed judgment by these agents due to cognitive bias as an inescapable element of individual and group decision-making (Janis, 1972; Kahneman et al., 1982; Bazerman and Watkins, 2004; Bazerman and Malhotra, 2006; Prentice, 2000, 2003; Coffee, 2006).

Biased decisions in the boardroom are suggested to be a major contributing factor to what ultimately might be seen as fraudulent, imprudent or destructive behavior of executive management and the acquiescence (or ignorance) to such activities by a board (Gwilliam and Marnet, 2010). A board operates within a framework of dependence, social ties, loyalties, and behavioral norms which forms an environment that can significantly undermine a board's monitoring function (Clarke et al., 2003; Coffee, 2006; Marnet, 2008). Regardless of the competence, good faith and integrity of board members, subconscious cognitive processes prevent a board's decisions from being unaffected by heuristics (mental shortcuts) and socialising effects, which can create a situation where competent individuals can passionately believe that 
they are making a sound judgment when they are not (Kahneman et al., 1982; Kahneman and Lovallo, 1993; FRC, 2011). Biased decision-making can occur in the absence of direct or indirect monetary incentives and a strong argument can be made that parties with an interest in viewing facts in a certain light are incapable of independent and objective judgment (Prentice, 2000; Bazerman et al., 2002; Bazerman and Watkins, 2004; Moore et al., 2010). Factors known to distort judgment include conflicts of interest, deference to authority, peer pressure, emotional attachments, and inappropriate reliance on prior experience, beliefs and decisions (Kahneman and Tversky, 1973; Kahneman et al. 1982; Jolls et al., 1998; Thaler, 2000; Rabin, 2002). Bazerman et al. (2002) note a particular vulnerability of judgment to subconscious motivation, making, inter alia, reference to a tendency to excessively discount facts that contradict desirable conclusions, whilst uncritically embracing evidence that supports prior positions (Babcock and Loewenstein, 1997; Prentice, 2003; Coffee, 2006).

An emphasis on group cohesion and unanimous decision-making, not untypical during boardroom interaction, can further diminish the effectiveness of a board's monitoring function (Janis, 1972, 1989; Forbes and Watson, 2010). The greater is group cohesion, the more prevalent are problems related to group decision-making (Janis, 1972, 1989). In the boardroom, this can be reflected in pressure towards conformity, rationalization of decisions taken, inappropriate loyalties towards a longserving CEO, and a reluctance to raise critical concerns (Lee et al., 2008; Forbes and Watson, 2010). Forbes and Watson (2010) note that organizations characterised by "strong managers and weak owners" (Roe, 1994) expose themselves to "destructive leadership" risks (Padilla et al., 2007) due to inappropriate board loyalty 
biases, little mitigated by current corporate governance codes. The sense of being in control can cause an initial reluctance by board members to grasp the magnitude of problems once these emerge (Bazerman and Malhotra, 2006), while dissonance reduction (Festinger, 1957) can further delay timely intervention by a board to avoid significant, and at times fatal, damage to an organization (Bazerman et al., 2002; Forbes and Watson, 2010).

Mere exhortations to 'be mindful of bias' are likely to be insufficient, since individuals, even where they accept the presence of bias in their own judgment, are typically unable to sufficiently adjust for its effects without the assistance of appropriate decision aids (Kahneman et al. 1982; Tversky and Kahneman, 1987; Bazerman and Moore, 2008). In a governance context, the effects of bias in judgment suggests the need for an adoption of practices and regulations directly aimed at moderating its impact on the decision-making processes of boards (Bazerman and Watkins, 2004; Bazerman and Malhotra, 2006; Merkhofer, 2012). Such recommendations go beyond more traditional calls for an enhancement of board members' expertise in, for example, accounting and finance, supported by formal training programs, induction sessions, and the periodic updating of skills (SOX, 2002; Clarke et al., 2003; Higgs, 2003; ICSA, 2010; FRC, 2010, 2011). Rather, initiatives aimed at debiasing the boardroom seek to institutionalise a reflection on the processes by which decisions are reached. If successful, such initiatives can act as circuit breakers that may prevent flawed initial board decisions from turning into serious problems for organizations (Staw, 1976; Bazerman and Watkins, 2004; Balogun and Johnson, 2005; FRC, 2011). 
A range of practices may be employed to counter the impact of bias (Bazerman and Watkins, 2004; Merkhofer, 2012). A board might, for example, provide full but temporary membership to outsiders tasked to identify weaknesses in the quality of the decision-making and control processes on the board. This can allow a board to change from a largely passive recipient of information (Peck, 1995) to one which challenges executive presentations in the discharge of responsibilities (Langevoort, 2001a; Parker, 2008). To create an additional counterweight to a dominant senior manager (Lee et al., 2008), boards may wish to make greater use of a senior independent director to regularly discuss important decisions and proposals with other independent directors (FRC, 2011). Critically, boards are encouraged to adopt processes aimed at preventing the approval of proposals without due diligence, and a subsequent escalation of commitment (Staw, 1976), by, for example: Splitting the decision process into separate discussions on concept, proposal for discussion, and a proposal for decision (ICSA, 2010); commissioning independent reports; seeking the advice of outsiders; requiring decision makers to justify their information choices; appointing 'devil's advocates' to seek weaknesses in a proposal; deliberately framing of decision problems in multiple ways; and seeking dis-confirmatory information, that is, to look for information and arguments that do not support a proposal (Bazerman and Watkins, 2004; Bazerman and Moore, 2008; FRC,2011). For significant decisions, a board may consider allowing a separate group of directors, not involved in the proposal, to assess the appropriateness of the decision process, in addition to assessing the merits of the proposal itself (Merkhofer, 2012). 


\section{Conclusion}

The boardroom narrative has an increasingly important role in the governance of quasi-public sector organizations (and elsewhere) and the main objective of this research is to highlight behavioral causes for a reluctance of boards to explore issues on which formal forms of accountability remain silent. Cognitive bias is suggested to affect the control role of boards by inhibiting constructive debate and challenge, and by fostering an over-reliance on formal forms of accountability. This was observed at the Association, where the collegial, consensus-seeking atmosphere of board meetings, trust in the executive team, and faith in the competence of the Chair had first limited an adequate expression of issues critical to governance and accountability, and subsequently delayed the adoption of changes required to overcome a near fatal crisis. The presented analysis provides support for an institutionalised use of procedures aimed at mitigating the effects of bias on the quality of board decision-making. To allow extensions of the limited inferences that can be drawn by this study, further longitudinal research is encouraged to explore differences and similarities in the control orientation of private and not-for-profit sector boards. The paper also calls for further investigation into the effects of bias on the control processes at board level, and on the effectiveness of procedural means to mitigate its impact on boardroom decisions. 


\section{References}

APB, Auditing Practices Board (2012) 'Professional Scepticism', http://www.frc.org.uk/getattachment/1aecac64-6309-4539-a6d9690e67c93519/Briefing-Paper-Professional-Scepticism.aspx (Accessed on 29 June 2012).

Babcock, L. and Loewenstein, G. (1997) 'Explaining bargaining impasse: the role of self-serving biases', Journal of Economic Perspectives, Vol. 11, No. 1, pp.109126.

Balogun, J. and Johnson, G. (2005) 'From intended strategies to unintended outcomes: the impact of change recipient sensemaking', Organization Studies, Vol. 26, No. 11, pp.1573-1601.

Bazerman, M.H. Loewenstein, G. and Moore, D.A. (2002) 'Why good accountants do bad audits', Harvard Business Review, Vol. 80, No. 11, pp. 97-102.

Bazerman, M.H. and Malhotra, D. (2006) 'Economics wins, psychology loses, and society pays', in De Cremer, D., Zeelenberg, M., and Murnighan, K. (Eds.), Social Psychology and Economics, Lawrence Erlbaum Associates, Mahwah, NJ, pp.263-280.

Bazerman, M.H. and Moore, D. (2008) 'Judgment in Managerial Decision Making'. $7^{\text {th }}$ ed., Wiley, Hoboken, N.J.

Bazerman, M.H. and Watkins, M.D. (2004) 'Predictable Surprises: The Disasters You Should Have Seen Coming and How to Prevent Them', Harvard Business School Press, Boston, MA.

Bogt, H.J.T., Scapens, R.W. (2012) 'Performance management in universities: effects of the transition to more quantitative measurement systems', European Accounting Review, iFirst Article, pp.1-47.

Brennan, N. (2006) 'Boards of directors and firm performance: is there an expectations gap?', Corporate Governance: An International Review, Vol. 14, No. 6, pp.577-593.

Broadbent, J. and Guthrie, J. (2008) 'Public sector to public services: 20 years of "contextual" accounting research', Accounting, Auditing and Accountability Journal, Vol. 21, No.2, pp.129-169.

Brudney, V. (1982) 'The independent director - heavenly city or Potemkin village?', Harvard Law Review, Vol. 95, No. 3, pp.597-660. 
Bruijn, H. de (2007) Managing Performance in the Public Sector, Routledge, London and New York.

Cadbury, A. (1992) 'Report of the Committee on the Financial Aspects of Corporate

Governance: The Code of Best Practice', Professional Publishing, London.

Clarke, F.L., Dean, G.W. and Oliver, K.G. (2003) Corporate Collapse: Regulatory, Accounting and Ethical Failure, $2^{\text {nd }}$ ed., Cambridge University Press, Cambridge.

Coffee, J.C. (2006) Gatekeepers: The Professions and Corporate Governance, Oxford University Press, Oxford.

Collier, P.M. (2005) 'Governance and the quasi-public organization: a case study of social housing', Critical Perspectives on Accounting, Vol. 16, No. 7, pp.929-49.

Community Housing (2011) 'Drive for Innovation. The 2011 Financial Statements of Welsh Housing Associations', http://chcymru.org.uk/shadomx/apps/fms/fmsdownload.cfm?file_uuid=E0514BA C-F2E4-4615-B34B-198D5CA1B25F\&siteName=chc_dev_final (Accessed on 09 July 2012).

Daily, C.M., Ellstrand, A.E. and Johnson, J. (1996) 'Boards of directors: a review and research agenda', Journal of Management, Vol. 22, No. 3, pp.409-438.

DETR, Department of the Environment, Transport and the Region (2001) 'Guide to Social Rent Reforms', DETR, London.

Ezzamel, M. and Watson, R. (1997) 'Wearing two hats: the conflicting control and management roles of non-executive directors', in Keasey, K., Thompson, S. and Wright, M. (Eds.), Corporate Governance: Economic, Management and Financial Issues, Oxford University Press, Oxford, pp.54-79.

Fama, E.F. and Jensen, M.C. (1983) 'Separation of ownership and control', Journal of Law and Economics, Vol. 26, No. 2, pp.301-325.

Festinger, L. (1957) A Theory of Cognitive Dissonance, Stanford University Press, Stanford, CA.

FRC, Financial Reporting Council (2010) 'The UK Corporate Governance Code', http://www.frc.org.uk/getattachment/b0832de2-5c94-48c0-b771ebb249fe1fec/The-UK-Corporate-Governance-Code.aspx (Accessed 09 July 2012). 
FRC, Financial Reporting Council (2011) 'Guidance on Board Effectiveness', http://www.frc.org.uk/images/uploaded/documents/Guidance on board effectiveness FINAL6.pdf (Accessed 29 June 2012).

Forbes, W. and Watson, R. (2010) 'Destructive corporate leadership and board loyalty bias: a case study of Michael Eisner's long tenure at Disney corporation', paper presented at the Behavioural Finance Working Group Conference, 1-2 July 2010, Cass Business School, London, http://www.cass.city.ac.uk/_data/assets/pdf_file/0005/56372/2A_Forbes.pdf (Accessed 5 December 2011).

Guest, P.M. (2009) 'The impact of board size on firm performance: evidence from the UK', The European Journal of Finance, Vol. 15, No. 4, pp. 385-404.

Gwilliam, D. and Marnet, O. (2010) 'Audit within the corporate governance paradigm', working paper, No. 06/05, Exeter Business School, University of Exeter, http://business-

school.exeter.ac.uk/research/areas/topics/accounting/outputs/publication/?id=4 34 (Accessed 22 November 2011).

Heracleous, L.T. (1999) 'The board of directors as leaders of the organization', Corporate Governance: An International Review, Vol. 7, No. 3, pp.256-265.

Hermalin, B.E. and Weisbach, M.S. (1998) 'Endogenously chosen boards of directors and their monitoring of the CEO', American Economic Review, Vol. 88, No. 1, pp.96-118.

Higgs, D. (2003) 'Review of the Role and Effectiveness of Non-executive Directors', The Department of Trade and Industry, http://www.bis.gov.uk/files/file23012.pdf (Accessed 22 November 2011).

Hoskin, K. (1996) 'The awful Idea of accountability: inscribing people into the measurement of objects', in Munro, R. and Mouritsen, J. (Eds.), Accountability: Power, Ethos and the Technologies of Managing, International Thomson Business Press, London, pp. 265-282.

Hood, C. (1995) 'The 'New Public Management' in the 1980s: variations on a theme', Accounting, Organizations and Society, Vol. 20, No. 2/3, pp.93-109.

Hood, C. (2007) 'Public service management by numbers: Why does it vary? Where has it come from? What are the gaps and the puzzles?', Public Money and Management, Vol. 27, No. 2, pp.95-102. 
ICSA, Institute of Chartered Secretaries and Administrators, (2010) 'Improving Board Effectiveness',

http://www.icsa.org.uk/assets/files/pdfs/guidance/IBE\%20Second\%20Consultati on/Improving\%20Board\%20Effectiveness.pdf (Accessed 22 November 2011)

IFAC, International Federation of Accountants (2001) 'Governance in the Public Sector: A Governing Body Perspective (Study 13)', New York, NY. Janis, L.I. (1972) Victims of Groupthink: A Psychological Study of Foreign-Policy Decisions and Fiascos, Houghton Mifflin, Boston, MA. Janis, L.I. (1989) 'Groupthink: the desperate drive for consensus at any cost', in Ott, J.S. (Ed.), Classic Readings in Organizational Behavior, Wadsworth, Belmont, CA, pp.223-232.

Jolls, C., Sunstein, C.R. and Thaler, R.H. (1998) 'A behavioral approach to law and economics', Stanford Law Review, Vol. 50, No. 5, pp.1471-1550.

Kahneman, D. and Tversky, A. (1973) 'On the psychology of prediction', Psychological Review, Vol. 80, No. 4, pp.237-251.

Kahneman, D., Slovic, P. and Tversky, A. (Eds.) (1982) Judgment under Uncertainty: Heuristics and Biases, Cambridge University Press, New York, NY.

Kahneman, D. and Lovallo, D. (1993) 'Timid choices and bold forecasts: a cognitive perspective on risk taking', Management Science, Vol. 39, No. 1, pp., pp. 17-31. Kamuf, P. (2007) 'Accounterability', Textual Practice, Vol. 21, No. 2, pp.251-266. Kurunmäki, L., Lapsley, I. and Miller, P. (2011) 'Accounting within and beyond the state', Management Accounting Research, Vol. 22, No.1, pp.1-5.

Langevoort, D.C. (2001a) 'Monitoring: the behavioral economics of inducing agents' compliance with legal rules', research paper, No. C01-7, University of Southern California Law School, Center for Law, Economics \& Organization, : http://papers.ssrn.com/abstract_id=276121 (Accessed 22 November 2011).

Langevoort, D.C. (2001b) 'The human nature of boards: law, norms and the unintended consequences of independence and accountability', The Georgetown Law Journal, Vol. 89, No. 4, pp.797-832.

Lapsley, I. (2008) 'The NPM agenda: Back to the future', Financial Accountability and Management, Vol. 24, No. 1, pp.77-96.

Leatherwood, M.L. and O'Neal, D. (1996) 'The transformation of boards in corporate and not-for-profit sectors: diminishing differences and converging contexts', Corporate Governance: An International Review, Vol. 4, No. 3, pp.180-192. 
Lee, T.A, Clarke, F. and Dean, G. (2008) 'The dominant senior manager and the reasonably careful, skilful, and cautious auditor', Critical Perspectives on Accounting, Vol. 19, No. 5, pp.677-711.

Marnet, O. (2007) 'History repeats Itself: the failure of rational choice models in corporate governance', Critical Perspectives on Accounting, Vol. 18, No. 2, pp.191-210.

Marnet, O. (2008) Behaviour and Rationality in Corporate Governance, Routledge, London and New York, NY.

Marnet, O. (2011) 'Bias in the boardroom', International Journal of Behavioural Accounting and Finance (IJBAF), Vol. 2, No. 3/4, pp.238-251.

McLean, I., Haubrich, D. and Gutiérrez-Romero, R. (2007) 'The perils and pitfalls of performance measurement: the CPA regime for local authorities in England', Public Money and Management, Vol. 27, No. 2, pp.111-117.

McSweeney, B. (1996) 'The arrival of a type of accountability: explaining the imposition of management by accounting', in Munro, R. and Mouritsen, J. (Eds.), Accountability: Power, Ethos and the Technologies of Managing, International Thomson Business Press, London, pp.201-224.

Merkhofer, L. (2012) 'Choosing the Wrong Portfolio of Projects', http://www.prioritysystem.com/reasonsabstract.html (Accessed at 11 July 2012).

Miller, J.L. (2002) 'The board as a monitor of organizational activity: the applicability of agency theory to nonprofit boards', Nonprofit Management and Leadership, Vol. 12, No. 4, pp.429-450.

Moore, D.A., Tanlu, L. and Bazerman, M.H. (2010) 'Conflict of interest and the intrusion of bias', Judgment and Decision Making, Vol. 5, No. 1, pp.37-53.

Mullins, D. (2010) 'Housing Associations', Third Sector Research Centre, Working Paper 16, http://www.tsrc.ac.uk/LinkClick.aspx?fileticket=qyS3AvWvt\%2Bk\%3D\&tabid=50 0 (Accessed on 09 July 2012).

O'Neal, D.E. and Thomas, H. (1995) "'Director networks/director selection: the board's strategic role', European Management Journal, Vol. 13, No. 1, pp.7989.

Padilla, A., Hogan, R. and Kaiser, R. (2007) 'The toxic triangle: destructive leaders, susceptible followers and conducive environments', The Leadership Quarterly, Vol. 18, No. 3, pp.176-194. 
Parker, L.D. (2003) 'Financial management strategy in a social welfare organization: a boardroom perspective', Financial Accountability and Management, Vol. 19, No. 4, pp.341-374.

Parker, L.D. (2008) 'Boardroom operational and financial control: an insider view', British Journal of Management, Vol. 19, No. 1, pp.65-88.

Peck, E. (1995) 'The performance of an NHS trust board: actors' accounts, minutes and observation', British Journal of Management, Vol. 6, No. 2, pp.135-156.

Pollitt, C. (2006) 'Performance information for democracy', Evaluation, Vol. 12, No. 1, pp.38-55.

Prentice, R.A. (2000) 'The case of the irrational auditor's securities fraud: a behavioral insight Into securities regulation', Northwestern University Law Journal, Vol. 95, No. 1, pp.133-220.

Prentice, R.A. (2003) 'Enron: a brief behavioral autopsy', American Business Law Review, Vol. 40, No. 2, pp.417-444.

Rabin, M. (2002) 'A perspective on psychology and economics', European Economic Review, Vol. 46, No. 4-5, pp.657-685.

Roberts, J. (1991) 'The possibilities of accountability', Accounting, Organizations and Society, Vol. 16, No. 4, pp.355-368.

Roberts, J. (1996) 'From discipline to dialogue: individualizing and socialising forms of accountability', in Munro, R. and Mouritsen, J. (Eds.), Accountability: Power, Ethos and the Technologies of Managing, International Thomson Business Press, London, pp. 40-61.

Roberts, J. (2001) 'Trust and control in Anglo-American systems of corporate governance: the individualizing and socialising effects of processes of accountability', Human Relations, Vol. 54, No. 12, pp.1547-1572.

Roe, M. (1994) Strong Managers, Weak Owners: The Political Roots of American Corporate Finance, Princeton University Press, Princeton, NJ.

SOX, Sarbanes-Oxley Act of 2002 (U.S. Senate, Pub.L. 107-204, 116 Stat. 745, enacted July 30, 2002).

Staw, B.M. (1976) 'Knee-deep in the big muddy: a study of escalating commitment to a chosen course of action', Organizational Behavior and Human Performance, Vol. 16, No. 1, pp.27-44. 
Thaler, R.H. (2000) 'From homo economicus to homo sapiens', The Journal of Economic Perspectives, Vol. 14, No. 1, pp.133-41.

Thorsen, E.J. (1996) 'Stress in academe: what bothers professors?', Higher Education, Vol. 31, No. 4, pp. 471-489.

Tang, C.P.Y. (2010) 'Trends in Housing Association Stock in 2009', Dataspring, Cambridge Centre for Housing and Planning Research, University of Cambridge, Cambridge.

TSA, Tenant Services Authority (2012) "2011 Global Accounts of Housing Providers", http://www.tenantservicesauthority.org/upload/pdf/2011_global_accounts_full_20 120326125913.pdf (Accessed on 09 July 2012).

Tversky, A. and Kahneman, D. (1987) "Judgment Under Uncertainty: Heuristics and Biases", Cambridge Press, Cambridge.

Wilcox, S. (2004) "UK Housing Review 2004/05", Coventry: Chartered Institute of Housing, http://www.york.ac.uk/res/ukhr/ukhr0506/index.htm (accessed 09 July 2012).

Woods, C. (2010) "Employee wellbeing in the higher education workplace: a role for emotion scholarship", Higher Education, Vol. 60, No. 2, pp.171-185. 